\title{
Emberkereskedelem újragondolva - a 2020. július 1-jén hatályba lépett rendelkezések hatékonysága ügyészi szemmel
}

\author{
Rethinking trafficking in human beings - \\ the effectiveness of the provisions that entered into force on \\ 1 July 2020 from a prosecutorial perspective
}

\author{
Huszár Julianna \\ Dr. legfőbb ügyészségi ügyész, \\ Legfőbb Ügyészség, \\ Kiemelt, Korrupciós és Szervezett Bünözés Elleni Ügyek Főosztálya \\ huszar.julianna@mku.hu
}

\begin{abstract}
Absztrakt
Cél: Az emberkereskedelem és kényszermunka törvényi tényállásának 2020ban történt módosítása a kialakult és kúriai döntésekkel megerősített jogalkalmazói gyakorlat átgondolását tette szükségessé. Bár a módosítást életre hívó törvény indokolása szerint a változtatás a szabályozás koherensebbé és átláthatóbbá tételét tűzte ki célul, a gyakorlat - egyelőre - értelmezési nehézségekkel küzd. A tanulmány ebben a helyzetben igyekszik megoldási javaslatokkal segíteni az alakuló joggyakorlatot.
\end{abstract}

Módszertan: A tanulmány az emberkereskedelem és kényszermunka miatt indult egyes büntetőeljárásokban észlelt jogalkalmazói bizonytalanságokból azonosítható, jellemzőnek látszó kérdésekre adható válaszok átgondolásával tesz kísérletet a gyakorlati munka támogatására.

Megállapítások: A téma összetettségére, az egyes büntető ügyek egyedi jellemzőire figyelemmel számos azonosított problémára jelen tanulmányban nem adható válasz, így kizárólag a legtöbbször visszatérő dilemmák kerültek górcső alá.

Érték: A szabályozás hátterében álló jelenség komplexitása, és a gyakorlat kiskorúsága nyilvánvalóvá teszi, hogy a témával újra és újra foglalkoznia kell a szakembereknek.

Kulcsszavak: emberkereskedelem, Magyarország, törvénymódosítás, toborzás 


\begin{abstract}
Aim: The amendment of the legal situation of trafficking in human beings and forced labor in 2020 required a rethink of the established practice, which was confirmed by the decisions of the Curia. And although, according to the explanatory to the law that introduced the amendment was aimed at making the regulation more coherent and transparent, the practice - for the moment faces difficulties of interpretation. In this situation, the study tries to help the emerging practice with suggestions for solutions.

Methodology: The study attempts to support practical work by considering responses to the typical questions identified in some criminal proceedings for trafficking in human beings and forced labor.

Findings: Given the complexity of the topic and the unique characteristics of each criminal case, many of the problems identified cannot be addressed in the present study, so only the most recurring dilemmas have come under scrutiny. Value: The complexity of the underlying phenomenon and the minority of the practice make it clear that professionals need to address the topic over and over again.
\end{abstract}

Keywords: human trafficking, Hungary, amendment, recruitment

\title{
Bevezetés
}

A Btk. ${ }^{1}$ emberkereskedelmet érintő tényállásának 2020. július 1-jétől hatályos változása, ha nem is alapvetően változtatta meg a joggyakorlatot, de a már korábbról ismert fogalmak jogalkotó által létrehozott új koncepció keretében történő át- és újragondolását, a már nem használható panelek elvetését, az átkomponált törvényi tényállásban megjelenő szabályozási elgondolás értelmezését, és az elmélet hatékony gyakorlatra váltásának kidolgozását tették és teszik szükségessé.

\section{Régi-új elem: a kiszolgáltatott helyzet}

\section{Kiszolgáltatott-e a kiszolgáltatott személy?}

A 2020. július 1-jét megelőzően hatályban volt Btk. sem határozta meg a kiszolgáltatott helyzet fogalmát, az ügyészségi gyakorlat - a Legfőbb Ügyészség

1 2012. évi C. törvény a Büntető Törvénykönyvről. 
iránymutatása alapján - a nemzetközi normákban, így az Egyesült Nemzetek keretében, Palermóban, 2000. december 14-én létrejött, a nemzetközi szervezett bünözés elleni egyezménynek az emberkereskedelem, különösen a nők és gyermekek kereskedelme megelőzéséről, visszaszorításáról és büntetéséről szóló jegyzőkönyvében (kihirdette a 2006. évi CII. törvény, a továbbiakban: Palermói Egyezmény) ${ }^{2}$, illetve az emberkereskedelem megelőzéséröl, és az ellene folytatott küzdelemröl, az áldozatok védelméröl, valamint a 2002/629/IB tanácsi kerethatározat felváltásáról szóló, 2011. április 5-i 2011/36/EU európai parlamenti és a tanácsi irányelvben (a továbbiakban: Irányelv) meghatározott elveknek megfelelően a kiszolgáltatott helyzetet akként határozta meg, hogy az már akkor is megállapítható, ha a passzív alany elfogadható választási lehetőség hiányában saját elhatározásából végez prostitúciós tevékenységet, egyéb munkát, illetve munkajellegü tevékenységet.

Azonban a nyomozások feletti felügyelet és a nyomozások irányítása során az ügyészségeknek - és az ügyészségeken keresztül a nyomozó hatóságoknak - problémát jelentett egyes esetekben már a korábbi Btk. hatálya alatt is az elfogadható választási lehetőség értelmezése, gyakorlati alkalmazása. A bizonytalanságot tovább növelte az a tény is, hogy egyes törvényszékek az ügyészségi értelmezést el nem fogadva a kiszolgáltatott helyzetet nem találták megállapíthatónak, és emberkereskedelem büntette helyett kerítés büntettében állapították meg a vádlottak büntetőjogi felelösségét.

Ilyen esetekben a passzív alanyok élethelyzetükből fakadó egzisztenciális kiszolgáltatottságát a törvényszékek nem tekintették olyan mérvü kiszolgáltatottságnak, amely az emberkereskedelem törvényi tényállásában szereplö kiszolgáltatott helyzet megállapítására alkalmas lett volna. Emberkereskedelem helyett kerítés megállapítására került sor olyan passzív alanyok esetében, akik alacsony intellektusú, csekély müveltségü és iskolázottságú, jövedelemforrást biztosító szakmával nem rendelkező, megfelelő lakóhely nélküli, ugyanakkor esetleg (több) gyermeket nevelö személyek voltak, és adott élethelyzetükben például prostitúciós tevékenység útján próbáltak bevételhez jutni, és ezen élethelyzetüket felismerve a terheltek őket az addiginál nagyobb kereseti lehetöség ígéretével külföldön folytatandó prostitúciós tevékenység végzésére vették rá, saját anyagi hasznuk reményében, a passzív alanyok által nyújtandó szolgáltatások feltételeit, a munkavégzés időtartamát ugyanakkor meghatározva.

2 2006. évi CII. tv. az Egyesült Nemzetek keretében, Palermóban, 2000. december 14-én létrejött, a nemzetközi szervezett bünözés elleni egyezménynek az emberkereskedelem, különösen a nők és gyermekek kereskedelme megelőzéséről, visszaszorításáról és büntetéséről szóló jegyzőkönyve kihirdetéséről, 3. §3. cikk a)-b)pont. 
Az ilyen tartalmú döntések figyelmen kívül hagyják, hogy ma Magyarországon foglalkoztatáspolitikai szempontból hátrányos helyzetủ személynek tekinthető többek között az, aki legfeljebb alapfokú iskolai végzettséggel rendelkezik, a saját háztartásában legalább egy 18 évesnél fiatalabb gyermeket egyedül nevel, vagy akár foglalkoztatás megkezdését megelőzően letartóztatásban volt, szabadságvesztés vagy elzárás büntetését töltötte. Ez a bírói értelmezés nem tükrözi a hátrányos helyzet kialakulásának legfontosabb társadalmi okait, a földrajzi adottságokat, a gazdasági körülményeket (mélyszegénység, munkanélküliség, hajléktalanság), a nyelvi- és kulturális hátteret, a képzettséget, illetve az ismerethiányt, miközben az ilyen élethelyzetben lévő személy kihasználását - a passzív alany tág értelemben vett körülményei miatt - nem lehetne kisebb súlyú büncselekménynek tekinteni.

A problémát a módosítás sem oldotta meg, hiszen a kiszolgáltatott helyzet definícióját a Btk. továbbra sem határozza meg. Erre figyelemmel a tévesnek tartott egyes eseti döntésekben megjelenő bírósági értelmezés tételes jogi cáfolata nem adható meg, annak ellenére, hogy az ügyészségi joggyakorlat által alkalmazott elvek mentén történő gondolkodást a hivatkozott, részben a nemzeti jog részévé is tett nemzetközi normák megerősítik.

\section{Nincs új a „Btk.” alatt}

Az egyes eseti döntésekben megjelenő bírósági álláspont ugyanakkor ellentétesnek látszik a törvény szellemével is. A kiszolgáltatott helyzet, pontosabban a kiszolgáltatott élethelyzet az emberkereskedelem és kényszermunka törvényi tényállásán kívül egy további diszpozícióban, a kiszolgáltatott személy megalázása (Btk. 225. §) törvényi tényállásában is megjelenik. A törvény maga ebben az esetben sem ad értelmező rendelkezést arra, hogy a kiszolgáltatottság alatt mit kell érteni, de a törvényhelyhez füzött indokolás rögzíti, hogy a fogalom értelmezése során annak hétköznapi nyelvi jelentéstartalmát kell alapul venni. Ez a meghatározás szintén nem egzakt, egyéni érzékenységtől függhet, hogy kit tekint a jogalkalmazó kiszolgáltatott személynek, de segítséget jelent a gondolkodás irányának megválasztásához. Így például a szó szinonimáiból kiindulva (védtelen, sérülékeny, sebezhető) (URL1), vagy a pénzügyi szektor által is használt „élethelyzetből adódóan kiszolgáltatott ügyfél” (azok az ügyfelek, akik éppen gyászidőszakot élnek meg, egzisztenciális sokkot élnek át, válás vagy szakítás után vannak, büntetőeljárás zajlik ellenük, esetleg hazájukat elhagyva menekültként vagy bevándorlóként új életet kezdenek egy ismeretlen országban) (URL2) fogalmát használva pontosabb meghatározás adható. 
A törvény a $225 . \S^{3}$ esetén kiszolgáltatott élethelyzetet kíván meg a törvényi tényállás megállapításához. A törvény indokolása pedig azt mondja, hogy az élethelyzet a helyzethez képest több, az élethelyzet a helyzet tartós állapota. Ide tartozik az indokolás szerint például valakinek a társadalomban elfoglalt hátrányos helyzete, amely körülmény elöidézheti a kiszolgáltatottságot. A helyzet (amely fogalom az emberkereskedelem és kényszermunka tényállásában szerepel) pedig - törvény indokolása szerint - a külső és belső viszonyok, körülmények összessége. A fentiek értelmében a kiszolgáltatott helyzet megállapításához elegendő az is, hogy valaki ne tartósan, hanem akár alkalmilag, átmenetileg legyen olyan helyzetben, hogy az elkövető akaratának megfelelő magatartást hajlandó legyen tanúsítani. ${ }^{4}$

A kiszolgáltatott helyzet megállapítása különösen akkor jelent nehézséget a gyakorlatban, amikor a passzív alany és az elkövető azonos élethelyzetben vannak, külső viszonyaik megegyeznek. Ilyen élethelyzetről van szó, ha mind a passzív alany, mind az elkövető a gyermekvédelmi szakellátásban kényszerülnek felnőni, azaz mindketten tizennyolc év alattiak, mindketten nélkülözik egy jól funkcionáló család nyújtotta anyagi, erkölcsi, mentális stb. biztonságot. A helyzet értékelése során azonban el kell fogadni azt, hogy a szakellátásban élö, tizennyolcadik életévüket be nem töltött személyek között különösen jelen van a hierarchia, az alá-fölérendeltségi, a befolyásolási, illetve más egyéb hatalmi viszony, az erőszak. Pusztán az a tény, hogy az elkövetői és a passzív alanyi oldal szereplői egyaránt szakellátásban, azaz nyilvánvalóan a családban felnövő gyerekekhez képest egyaránt hátrányosabb, kiszolgáltatottabb helyzetben vannak nem zárja ki ezen helyzet további differenciálódásának a lehetőségét, azaz azt, hogy az egyik gyermek, a másikhoz képest hátrányosabb, kiszolgáltatottabb helyzetben van. A kiszolgáltatott helyzetet azonban ilyen esetben sem lehet vélelmezni, azt bizonyítani kell, ugyanakkor szem elött kell tartani, hogy a nyomozás során a passzív alanyi oldalon a tizennyolcadik életév be nem töltése - akár felnőttkorú, akár fiatalkorú az elkövető - olyan indikátor, amely a kiszolgáltatott helyzet vizsgálata szükségességének irányába mutat.

\section{$A z$ „önkéntes szexmunka” és társai}

A jelenleg hatályos törvény azáltal, hogy nem a kiszolgáltatott helyzet kihasználását rendeli büntetni, hanem a kiszolgáltatott helyzetben lévő személy

3 A Büntető Törvénykönyvről szóló 2012. évi C. törvény 225. §-ának részletes indokolása közlönyállapot 2021. VII. 8. - 2021. XII. 31.

4 A Büntető Törvénykönyvről szóló 2012. évi C. törvény 225. §-ának részletes indokolása közlönyállapot 2021. VII. 8. - 2021. XII. 31. 
rábírását, a nemzetközi egyezménnyel ellentétesen ${ }^{5}$ a passzív alany önkéntességének tulajdonít jelentőséget, hiszen az a kiszolgáltatott helyzetben lévő passzív alany, aki ezen helyzetéből történő kilábalás érdekében maga keresi meg az elkövetöt azzal, hogy akár jogellenes cselekményben venne részt, akár szexuális cselekményt végezne, nem lesz a büncselekmény passzív alanya, hiszen nem valósul meg esetében rábírás az elkövető részéről. A módosítás így szükítette a védendő személyi kört, és nehézkesebbé is tette a bizonyítást. A jogalkotó ezzel párhuzamosan a jogalkalmazókat a rábírás emberkereskedelem és kényszermunka tényállása keretén belül történő (újra) értelmezésére kényszerítette.

A rábírás mint minden más fogalom a Btk.-ban, a törvény alkalmazása során csak egyféleképpen értelmezhető, nem adható tényállásonként eltérő tartalom hozzá, a kiszolgáltatott helyzetben lévő passzív alany „önkéntes csatlakozását” nem lehet rábírásként értelmezni.

A rábírás mint elkövetési magatartás számos törvényi tényállásban szerepel. Ilyenek például a tiltott sorozás (Btk. 152. §), öngyilkosságban közremüködés (Btk. 162. §), kóros szenvedélykeltés (Btk. 181. §), szexuális visszaélés (Btk. 198. §), prostitúció elősegítése (Btk. 201. §), kiskorú veszélyeztetése (Btk. 208. $\S$ ), és a már említett kiszolgáltatott személy megalázása (Btk. 225. §).

A Btk. 225. §-a úgy fogalmaz, hogy ,, Aki mást, annak kiszolgáltatott élethelyzetét kihasználva arra bír rá...”. A Btk. 192. §-a pedig úgy, hogy „Aki mást rendszeres előny szerzése céljából [...] szexuális cselekmény végzésére [...] a passziv alany kiszolgáltatott helyzetét kihasználva rábír...".

A két tényállás szövegezése az elkövetési magatartás, valamint a passzív alany személyének meghatározását tekintve megegyezik. A Btk. 192. §-ához füzött indokolás nem magyarázza meg a rábírást mint elkövetési magatartást, azonban a 225. § kapcsán nem marad adós ezzel, és ez a meghatározás megegyezik a más büncselekményekkel kapcsolatban adott, és a joggyakorlat által használttal.

Eszerint, és az emberkereskedelem és kényszermunka esetében is irányadó módon, a rábírás ténylegesen felbujtói tevékenységet, célratörő magatartást jelent, és megvalósulhat rábeszéléssel, kéréssel, felszólítással (vagy akár fogadás ajánlásával, látszólagos lebeszéléssel, ajándék vagy egyéb előny ígéretével), de mindenképpen olyan módon, ami szándékkiváltó, a passzív alanyt cselekvésre indítja. A cselekmény akkor tényállásszerü, ha az elkövető azzal a szándékkal cselekedett, hogy a kiszolgáltatott helyzetben levő személyt a törvényi tényállásban meghatározott magatartásra késztesse. A büncselekmény

5 2006. évi CII. tv. 3. § 3. cikk a) pont. 
a rábíró magatartás kifejtésével befejezetté válik, az eredménytelen rábírás előkészületi magatartás. ${ }^{6}$

A fentiek figyelembe vételével az elkövetőnek a prostitúció kedvezőbb körülmények között, nagyobb bevétellel történő végzését ígérő, majd azt elősegítő magatartása, amennyiben azt kiszolgáltatott helyzetben lévő, de korábban is prostitúciós tevékenységből élő személlyel kapcsolatban tanúsítja, rábeszéléssel, előny ígéretével megvalósított rábírásnak minősül, és ily módon az emberkereskedelem és kényszermunka büntette megállapítására alkalmas. Ebben az esetben lényegében arról van szó, hogy az elkövető a saját javára, saját rendszeres előnyszerzése érdekében kívánja rábírni a passzív alanyt, aki addig adott esetben másik elkövetőnek dolgozott, vagy akár „futtató” nélkül folytatta ezt a tevékenységet.

Abban az esetben azonban, ha az elkövető felbujtói magatartást nem tanúsít, csak „foglalkoztatja” a nála jelentkező, szexuális cselekmény végzésére vállalkozó személyeket, a kerítés büntette állapítható meg.

Az úgynevezett „loverboy” módszer esetén, amikor az elkövető érzelmeit tekintve megtéveszti, vagy akár hatalmi helyzetét, személyes befolyását érvényesíti a passzív alannyal szemben, a rábírás megvalósul. A módszer lényege pont az, hogy az elkövető nem vagy nehezen felismerhető módon, a külvilág számára kevéssé nyilvánvalóan hat a passzív alanyra. A kérés, kérlelés, sok esetben a látszólagos lebeszélés a passzív alanyban és a külvilágban az önkéntesség látszatát kelti, azonban a valóságban ez a passzív alanyra gyakorolt presszió, ráhatás, manipuláció.

\section{...és mi a helyzet a szerhasználókkal?}

A kábítószerfüggőség a központi idegrendszer olyan betegsége, amely során a szerfogyasztónál először a pszichés függés jelenik meg, ami az egyén „,szerkereső" magatartásában és szer utáni sóvárgásában fejeződik ki, ezt követően pedig kialakul a fizikai dependencia, melynek során a szerre jellemző elvonási tünetek állnak elő. A pszichés és fizikai függés pedig kiszolgáltatja a fogyasztót a szernek, illetve ezen keresztül a szerhez jutást biztosító személynek, és nem egyszer tragikus események (öngyilkosság) vetnek csak véget a függésnek. Az ilyen kiszolgáltatott helyzet értékelésére az emberkereskedelem és kényszermunka büncselekményével összefüggésben is szükség lehet, hiszen előfordulhat, hogy az elkövető kábítószerfüggő személyt bír rá vagy kényszerít szexuális

6 A Büntető Törvénykönyvről szóló 2012. évi C. törvény 225. §-ának részletes indokolása közlönyállapot 2021. VII. 8. - 2021. XII. 31. 
cselekmény végzésére, jogellenes cselekmény folytatására stb., sőt adott esetben a függőség kialakítására, fenntartására is törekszik egyúttal.

A jogellenes cselekményre rábírás vagy kényszerítés esetén számos megválaszolandó kérdés merül fel:

a) fenyegetéssel elkövetett kényszerítésnek vagy kiszolgáltatott személy rábírásának minősül-e az olyan helyzet kialakítása, amelyben a kábítószerfüggő személy részére a szerhasználatot feltétel teljesítésétől teszi függővé az elkövetö;

b) amennyiben kényszerítésnek minősül, akaratot hajlító vagy akaratot megtörő kényszerről van-e szó, és ennek következtében részére büntethetőséget kizáró vagy büntethetőséget korlátozó ok állapítható-e meg a kényszer hatása alatt elkövetett jogellenes cselekményt érintően, így a jogellenes cselekményt elkövetö személy passzív alany vagy terhelt-e az ügyben, és ezzel összefüggésben a kényszerítő személy közvetett tettese vagy felbujtója-e a jogellenes cselekménynek;

c) a kábítószerfüggő passzív alany sanyargatásának minősül-e a szer megvonása;

d) illetve, hogy az esetleges öngyilkossági kísérlet súlyos hátrány okozásának megfeleltethetö-e.

Az ilyen és hasonló esetekre általános érvényü iránymutatás természetszerüleg nem adható, az adott konkrét ügy körülményeit figyelembe véve, adott esetben szakértői vélemény birtokában lehet dönteni arról, hogy az emberkereskedelem és kényszermunka passzív alanyára az elkövető által gyakorolt hatás kényszerítésnek minősül-e vagy olyan rábírásnak, amely során a passzív alany cselekvési szabadsága nem sérül.

A kábítószer-használat azonosítása, ezen belül annak véleményezése, hogy a szerhasználat megvonása, a szerhez jutás feltételhez kötése megfeleltethetö-e olyan súlyos hátrány kilátásba helyezésének, amely alkalmas arra, hogy komoly félelmet keltsen, és ezáltal az érintett személy beszámítási képességére, ezen belül is az akaratnak megfelelö magatartás tanúsítására való képességére hatással van-e (vagy adott esetben már kóros elmeállapotot előidéző súlyos betegség lépett fel), egyértelmüen szakértỏi kompetencia. Szakértői vélemény birtokában lehet csak megalapozottan állást foglalni abban a kérdésben, hogy az elkövetési magatartás kényszerítésnek vagy rábírásnak minősül-e.

Amennyiben a rábírás mint elkövetési magatartás látszik megállapíthatónak, és a Btk. 15. §-ában meghatározott más büntethetőséget kizáró, illetve korlátozó ok sem áll fenn a jogellenes cselekmény önálló elkövetéséért, az emberkereskedelem és kényszermunka passzív alanya tettesként büntethető lesz, míg 
az ôt a jogellenes cselekmény elkövetésére rábíró személy felbujtóként vonható felelősségre.

Ezzel egyező a helyzet akkor is, ha a cselekményt kényszerítéssel elkövetett emberkereskedelemnek és kényszermunkának minősítik, és a jogellenes cselekményt elkövető, ugyanakkor fenyegetés hatása alatt álló személyt a kényszerítés csak korlátozta az akaratának megfelelö magatartás tanúsításában.

Csak az akaratot megtörő fenyegetés teremt olyan helyzetet, amelyben a jogellenes cselekményt elkövető, ugyanakkor az emberkereskedelem és kényszermunka passzív alanyának minősülő, kényszer hatása alatt álló személy mentesül a büntetőjogi felelösségre vonás alól, és ebben az esetben a kényszerítö személy a Btk. 13. § (2) bekezdése értelmében mint közvetett tettes felel a büncselekmény elkövetéséért.

A jogellenes cselekmény elkövetésére rábírással vagy kényszerítéssel megvalósított emberkereskedelem és kényszermunka elkövetője a jogellenes cselekményért a rábírt vagy kényszerített személy beszámítási, ezen belül is akaratnyilvánítási képességétől függően minősülhet a jogellenes cselekmény közvetett tettesének vagy felbujtónak.

A szakértői vélemény birtokában lehet állást foglalni abban a kérdésben is, hogy a szer megvonása a sanyargatás mint minősítő körülmény megállapítására alkalmas-e. A szakértöi vizsgálat az adott személyt ért hatások és az öngyilkossági kísérlet közötti okozati összefüggést igazolhatja, és megkönnyítheti a súlyos hátrány okozásának megállapítását

\section{Toboroz, átad, átvesz...}

A Btk. 192. § (2) bekezdésében - illetve a (4) bekezdésben - meghatározott elkövetési magatartásokhoz a (3) bekezdésben meghatározott elkövetési magatartásokat a jogalkotó előkészületi jellegü, illetve bünsegédi magatartásként kapcsolja, a két típusú elkövetési magatartás között tulajdonképpen cél-eszköz viszonyt létesítve, mivel a törvény megfogalmazásából az következik, hogy a toboroz, átad, átvesz, elad, megvásárol, elcserél, ellenszolgáltatásként átad vagy átvesz, másnak megszerez, szállít, elszállásol, elrejt, azaz (3) bekezdésben meghatározott elkövetési magatartásokat ezek elkövetője a (2) bekezdésben - illetve a (4) bekezdésben - meghatározott rábírás és kényszerítés megvalósítása érdekében tanúsítja.

A törvény indokolása értelmében a (3) bekezdés az emberkereskedelem azon mozzanatát rendeli önállóan büntetni, amellyel a rendszeres előnyszerzésre irányuló büncselekmény szándékos elősegítése történik. Ehhez nem szükséges, hogy a (3) bekezdés elkövetöje a (2) bekezdés - illetve a (4) bekezdés - szerinti 
célzatot átvegye, elegendő a (2) bekezdésben meghatározott folyamatra irányuló, más által tanúsított magatartás felismerése, és az annak érdekében történő alkalmi elkövetés is. ${ }^{7}$

Természetszerü, hogy a fenti két bekezdés egymáshoz való viszonya értelmezésének kérdése leginkább akkor merül fel, amikor a két bekezdésben meghatározott elkövetési magatartásokat különböző személyek tanúsítják.

A törvény szövegezéséből és indokolásából nemcsak az olvasható ki, hogy a (3) bekezdésben meghatározott egyes elkövetési magatartások tanúsítása rendszeres előnyszerzési cél hiányában is tényállásszerü, hanem az is, hogy ezen magatartások tanúsítása az emberkereskedelem büntettének megállapítására abban az esetben is alkalmasak, ha elkövetőjük nincs pontosan tisztában azzal, hogy a (2) bekezdésben - illetve a (4) bekezdésben - meghatározott elkövetési magatartások közül melyiket, illetve milyen módon kívánja, tervezi megvalósítani ezen cselekmény elkövetöje. Elegendő, ha a tudattartalma átfogja azt, hogy az általa toborzott, átadott, átvett, eladott, megvásárolt, elcserélt, ellenszolgáltatásként átadott vagy átvett, másnak megszerzett, szállított, elszállásolt, elrejtett személyt a (2) illetve a (4) bekezdésben meghatározott folyamatban valaki más ki vagy fel akarja használni.

\section{A toborzás és a Btk. 192. § a) pontjában meghatározott rábírás viszonya}

A toborzás egy olyan fogalom, amelynek a definícióját a jogalkotó hosszú ideje nem adja meg, és mivel toborzással elkövetett emberkereskedelem büntette miatt elenyésző számban indult büntetőeljárás, azt a gyakorlat sem tudta kidolgozni. A csekély számú eljárásnak vélhetően az az oka, hogy az elkövetők felhíváson túlmutató magatartása is tetten érhető volt az elmúlt időkben, ezért ezzel a tulajdonképpeni előkészületi jellegü magatartással nem kellett foglalkozni, nem kellett alkalmazni azt. Az elkövetői attitüdök változnak, az elkövetők még jobban rejtőzködnek, leplezik a cselekményüket, számolnak a velük szemben alkalmazott leplezett eszközökkel, de a passzív alanyokkal történő kapcsolatfelvételt elkerülni nem tudják, ezért a toborzás vizsgálatának egyre nagyobb hangsúlyt indokolt kapnia.

Definíció hiányában az értelmezéshez a tiltott toborzás tényállásához füzött törvényi indokolásból kiolvasható magyarázatot, valamint a Btk.-hoz füzött,

7 A Büntető Törvénykönyvről szóló 2012. évi C. törvény 192. §-ának indokolása közlönyállapot 2021. VII. 8. - 2021. XII. 31. 
elsősorban az ügyészek számára készített kommentárban található magyarázatot lehet és kell igénybe venni. Ezek szerint a toborzás olyan aktív magatartás, amely kialakítja másban az elhatározást az önkéntes csatlakozásra (Miskolczi, 2021). A toborzás lényegét tekintve önkéntes csatlakozásra történő felhívás.

Amennyiben a toborzás eredményes, azaz az elkövető felhívásására a paszszív alany beleegyezik más(ok)nak nyújtandó szexuális cselekmény végzésébe, jogellenes cselekmény folytatásába, munkavégzésbe stb., már nem toborzásról beszélünk, hanem rábírásról, és a Btk. 192. § (2) bekezdés a) pontja szerinti emberkereskedelem állapítható meg abban az esetben, ha a passzív alany az itt meghatározott kritériumoknak megfelel, azaz - és a gyakorlatban leginkább -, ha kiszolgáltatott helyzetben van. Ez az eset természetszerüleg akkor áll fenn, ha a toborzás és a későbbi rábírás elkövetöje ugyanazon személy.

Nem jelent problémát a Btk. 192. § (3) bekezdése szerinti (eredményes) toborzás és a (2) bekezdés a) pontja szerinti rábírás megállapítása akkor sem, ha a két elkövetési magatartást különböző személyek tanúsítják és a passzív alany a Btk. 192. § (2) bekezdés a) pontjában meghatározott speciális jellemzőknek megfelel.

Felmerül azonban a kérdés, hogy amennyiben a passzív alany nem rendelkezik a Btk. 192. § (2) bekezdés a) pontja szerinti speciális jellemzőkkel, azaz ha például nincs kiszolgáltatott helyzetben, azonban az elkövető (akár saját javára, akár más érdekében) őt rendszeres előnyszerzés céljából eredményesen felhívta (eredményesen toborozta) szexuális cselekmény végzésére (jogellenes cselekmény folytatására, munkavégzésre stb.), a Btk. 192. § (3) bekezdése szerinti „toborzásos” emberkereskedelem megállapítható-e. Akkor is ez a kérdés merül fel, ha az elkövető cselekménye nem mutat túl a felhíváson, vagy további elkövetői magatartás nem bizonyítható, viszont az elkövetői oldalon a rendszeres előnyszerzési cél megállapítható, legyen szó akár saját előny, akár más személy által realizálni kívánt előnyről. Ezzel a problémával szembesülünk akkor is, ha a toborzás eredménytelen volt.

A Btk. 192. § (2) bekezdés a) pontjában meghatározott kritériumok nélküli (nem kiszolgáltatott, nem befolyásolt stb.) személy passzív alanya lehet a Btk. 192. § (3) bekezdésében meghatározott elkövetési magatartásoknak, mivel ezen törvényi tényállás megállapításához nem szükségesek speciális jellemzők a passzív alanyi oldalon. A tényállás úgy fogalmaz, hogy „,Aki mást a (2) bekezdésben meghatározott cselekmény megvalósitása érdekében toboroz, átad [...] büntett miatt két évtöl nyolc évig terjedö szabadságvesztéssel büntetendö."

Hangsúlyozni szükséges azt is, hogy amennyiben a felhíváshoz erőszak, fenyegetés társul, toborzásról (önkéntes csatlakozásra felhívásról) nem lehet szó. Toborzásról akkor sem beszélhetünk, ha a Btk. 192. § (2) bekezdés a) pontjában - illetve a (4) bekezdésben - meghatározott módon törekszik - eredménytelenül 
- rábírni a passzív alanyt az elkövető. Amennyiben akár a kényszerítés, akár a Btk. 192. § (2) bekezdés a) pontja szerinti rábírás, azaz a megtévesztés, a hatalmi viszonnyal visszaélés, a kiszolgáltatott helyzet kihasználása eredménytelen volt, a Btk. 192. § (2) bekezdése - illetve (4) bekezdése - szerinti emberkereskedelem büntettének kísérletéről van szó.

\section{Másnak megszerzés}

2020. július 1. napjáig az emberkereskedelem tényállásában meghatározott „másnak megszerzést” a gyakorlat egyértelműen azonosította a kerítés törvényi tényállásában használt hasonló fogalommal.

Az azonosítás nem teljesen helyénvaló, figyelemmel arra, hogy a kerítés büntette a „szexuális cselekmény végzésére másnak megszerez” kifejezést használta, míg az emberkereskedelem akkor hatályos szabályozása egyrészt, „az eladás, megvásárlás, elcserélés, ellenszolgáltatásként átadás vagy átvétel megvalósítása érdekében történő másnak megszerez”, másrészt a „,kizsákmányolás céljából másnak megszerez" kifejezést használta, azaz a 2020. július 1 -je előtt hatályban volt törvény rendelkezései szerint is az emberkereskedelem tényállásán belüli másnak megszerzés tágabb kört ölelt fel, mint a kerítés tényállásában szereplő hasonló, ám a kontextusra tekintettel lényegesen szükebb értelmü kifejezés.

A másnak megszerzés, a cél megjelölése nélkül, önmagában az érintettek közvetlen kapcsolatának megteremtését jelentette korábban is, ami a kerítés esetén a szexuális cselekmény végzésének céljával, míg emberkereskedelem esetén eladás, megvásárlás stb., illetve kizsákmányolás céljával történő megszerzést jelentett.

A törvény módosítása sem idézett elő más helyzetet. Azaz a Btk. 192. § (3) bekezdésében meghatározott „másnak megszerzés” az érintettek közvetlen kapcsolata megteremtésének lehetősége azzal, hogy a „más” az emberkereskedelem tényállásának kontextusában a (2) bekezdés elkövetőjével azonosítható, mivel a 192. § (2) és (3) bekezdése egymással szoros, cél-eszköz kapcsolatban van.

\section{Az emberkereskedelem és kényszermunka tényállásán belüli halmazat}

A jogalkalmazás során az egyik legnehezebb terület a megállapított történeti tényállások helyes minősítése, ezen túl pedig annak eldöntése, hogy az adott 
elkövetői magatartások halmazatban történő megállapításának helye van-e, vagy azok a folytatólagosság egységébe tartoznak.

Az emberkereskedelem és kényszermunka újraszabályozásának célja a minősítési rendszer koherensebbé, átláthatóbbá tétele volt. ${ }^{8}$ Talán az eltelt rövid időre és arra figyelemmel, hogy az új szabályozási rendszerben minősített büncselekmények miatt indult büntetőeljárásokban még nem született ítélet, bizonytalanság észlelhető a jogalkalmazás szintjén.

\section{A Btk. 192. § (2) bekezdés a) vagy b) pontjának és a Btk. 192. $\S$ (1) bekezdés a) pontjának halmazata}

Számos esetben fordul elő, hogy a Btk. 192. § (2) bekezdés a) vagy b) pontjának - illetve a (4) bekezdésének - elkövetői a passzív alanyokat egymás között elcserélik, a passzív alanyt ellenszolgálatásként átadják-átveszik - a Btk. 192. § (1) bekezdés a) pontjában meghatározott elkövetési magatartásokat tanúsítják tudva azt, hogy a passzív alany fölött hatalmat szerző a passzív alanyt szintén szexuális cselekmény végzésére, munka jellegü tevékenység végzésére vagy jogellenes cselekmény folytatására bírja majd rá vagy kényszeríti.

Valójában ilyen esetekben az elcserélés, az ellenszolgáltatásként átadás-átvétel nem a Btk. 192. § (1) bekezdés a) pontjában, hanem a Btk. 192. § (3) bekezdésében meghatározott elkövetési magatartás megállapítására alkalmas, hiszen arra a 192. § (2) bekezdésben - illetve a (4) bekezdésben - meghatározott célból - rendszeres előnyszerzés érdekében munkavégzésre, munkajellegü tevékenység végzésére, jogellenes cselekmény folytatására, szexuális cselekmény végzésére - kerül sor.

A különböző elkövetési magatartások következménye ilyenkor jellemzően nem különül el, és mivel a létrejött büncselekménytöbbség a Btk. 6. § (2) bekezdés feltételeinek megfelel (sértetti azonosság, egységes akaratelhatározásból származás, rövid időn belül ismétlődő elkövetés) a folytatólagosság egysége rendszerint megállapítható, a részcselekmények elvesztik önállóságukat és egy büncselekményként értékelendők. Mindemellett ilyen esetben a Kúria 2/2018. számú BJE határozatának is jelentősége van.

8 A Büntető Törvénykönyvről szóló 2012. évi C. törvény 192. §-ának indokolása közlönyállapot 2021. VII. 8. - 2021. XII. 31. 


\section{A Btk. 192. § (2) bekezdés \\ a) pontja és b) pontjának halmazata}

E körben az előző pontban már említett, a Kúria gyermekpornográfia bűntette tekintetében a halmazat megállapításának kérdésével foglalkozó 2/2018. jogegységi döntése tekintendő irányadónak.

A Kúria elvi éllel mondta ki azt, hogy:

- büncselekményi egységet csak az azonos törvényi tényállásba ütköző magatartások képeznek;

- ha ugyanazon passzív alany sérelmére különböző elkövetési magatartásokat valósít meg az elkövető, egységesen a legsúlyosabb büntetési tétellel fenyegetett büncselekmény valósul meg;

- ha az elkövető különböző passzív alanyok sérelmére, különböző elkövetési magatartásokat valósít meg, valóságos halmazat jön létre. ${ }^{9}$

A Kúria ugyanakkor a fenti határozatában azt is rögzítette, hogy az egység és a halmazat elhatárolása tekintetében nincs egységes rendező elv, azt az irányadó törvényi szabályozás alapul vételével a bírói gyakorlat alakítja ki. Emellett kifejtette a Kúria azt is, hogy többnyire halmazatot képez a passzív alanyok száma, az adott jogtárgy többszöri sérelme, különböző jogtárgyak sérelme, illetve, ha a megvalósított tényállások között nincs szükségszerü kapcsolat; a büncselekményi egység általános feltétele ugyanakkor az, hogy csak egymással szoros időbeli és térbeli kapcsolatban álló magatartások tartozhatnak bele. ${ }^{10}$

A fentiek figyelembevétele mellett megállapítható, hogy bár a Btk. 192. § (2) bekezdés a) és b) pontjában meghatározott elkövetési magatartások különböző elkövetési magatartások, ugyanakkor időben és térben szorosan összefüggő, ugyanazon passzív alany sérelmére megvalósított elkövetési magatartások, amelyeket a jogalkotó ugyanolyan büntetési tétellel fenyeget, ezért a folytatólagos egység megállapításának van helye.

A folytatólagosság egységébe tartozik az a cselekménysorozat is, amikor az elkövető ugyanazon passzív alany sérelmére, a passzív alany tizennyolcadik életévének betöltése elött, és azt követően is megvalósítja a büncselekményt. Ilyen esetben a minősítés a súlyosabb büntetési tétellel fenyegetett, a Btk. 192. $\S$ (5) bekezdés a) pontja szerinti elkövetési magatartás szerint alakul.

Amennyiben azonban az elkövető magatartása a Btk. 200. §-a szerinti kerítésnek minősül, majd időben és térben ezzel a cselekménnyel szorosan összefüggő,

9 Kúria 2/2018. számú BJE határozata.

10 Kúria 2/2018. számú BJE határozata. 
ugyanazon passzív alany sérelmére megvalósított, a Btk. 192. § (2) bekezdés b) pontjára figyelemmel a (4) bekezdés szerinti emberkereskedelem is megvalósult, a két büncselekmény halmazata állapítható meg, mert a különböző törvényi tényállásokat a folytatólagosság egységébe vonni nem lehet.

\section{Szexuális cselekmény végzésére és munkavégzésre (munkajellegü tevékenység végzésére, jogellenes cselekmény folyatására) rábírás, és/vagy kényszerítés halmazata}

Abban az esetben, ha az elkövető ugyanazon passzív alany sérelmére a különböző büntetési tételekkel fenyegetett szexuális cselekmény végzésére és munkavégzésre (munkajellegü tevékenység végzésére, jogellenes cselekmény folytatására) is irányuló emberkereskedelmet követett el az adott elkövetési időn belül, szintén a már hivatkozott Kúriai döntést kell irányadónak tekinteni, és ha ugyanazon passzív alany sérelmére különböző elkövetési magatartásokat valósít meg az elkövető, egységesen a súlyosabb büntetési tétellel fenyegetett büncselekmény valósul meg.

A több személy sérelmére elkövetett akár azonos, akár különböző elkövetési magatartások a Btk. 192. § (5) bekezdés d) pontja szerint minősülnek egységesen több ember sérelmére elkövetett emberkereskedelemnek, akár egyetlen akaratelhatározásból, tér- és időbeli összefüggésben, akár egymást követően vagy különböző időpontokban, eltérő akaratelhatározásból valósultak meg. Azonban a (6) bekezdésében meghatározott minősített esetek nem vonhatók az (5) bekezdés d) pontjának hatálya alá. Amennyiben több ember sérelmére elkövetett emberkereskedelemnek van tizenkét év alatti vagy olyan passzív alanya, akit érintően az életveszély vagy a különösen súlyos hátrány okozása állapítható meg, ez a részcselekmény nem lesz értékelhető az (5) bekezdés d) pontja szerint, a törvényi egység részeként, hanem attól elkülönülten a (6) bekezdés megfelelő pontja szerint minősülhet, azaz ilyen esetben e büncselekmények halmazata megállapítható.

\section{A személyi szabadság megsértése és az emberkereskedelem és kényszermunka viszonya}

A személyi szabadság megsértésének büntette az emberkereskedelem és kényszermunka büntettével egy fejezetben szabályozott büncselekmény. A két büncselekmény azonos jogtárgyat sért, más ember személyi szabadságát, azonban 
az emberkereskedelem és kényszermunka a személyi szabadság megsértéséhez képest speciális, így halmazatban történő megállapításuk kizárólag akkor lehetséges, ha az elkövetési magatartások időben és térben jól elkülöníthetők. Az 1978. évi IV. törvény 175 . § (2) bekezdése még akként rendelkezett, hogy aki emberkereskedelemmel összefüggésben megszerzett és a személyi szabadságától megfosztott passzív alany személyi szabadságának megfosztását fenntartja, és a passzív alanyt munkavégzésre kényszeríti, büntettet követ el, és két évtől nyolc évig terjedő szabadságvesztéssel büntetendő ${ }^{11}$. A Btk. 2020. július 1-jét megelőzően - mivel a „személyi szabadságtól megfosztás fenntartását" nehezen értelmezhetőnek tartotta a jogalkotó - a személyi szabadság megsértésének tényállásából ezt a fordulatot elhagyta, és külön tényállásban, kényszermunka alcím alatt rendelte büntetni a munkavégzésre kényszerítést ${ }^{12}$, majd ezt a tényállást hatályon kívül helyezte a 2020. évi V. törvény, és vált ily módon a munkáltatással összefüggő személyi szabadság megsértése az emberkereskedelem és kényszermunka büncselekményének részévé. Ezen elméleti alap szolgál magyarázatul egyben arra is, hogy a két büncselekmény halmazata - főszabály szerint - miért kizárt.

\section{Az emberkereskedelem és kényszermunka, valamint a kerítés viszonya}

Figyelemmel arra, hogy a módosítás továbbra sem rendezte megnyugtatóan a Btk. 200. §-ában szabályozott kerítés minősített eseteinek, és az emberkereskedelem és kényszermunka elkövetési magatartásainak viszonyát, a jogalkalmazásban továbbra is problémát jelent ezen büncselekmények elhatárolása, és esetleges halmazatuk megállapíthatósága.

Ismert olyan álláspont, amely szerint a jogalkotó a szexuális kizsákmányolás egyes eseteit nemcsak az emberkereskedelem és kényszermunka büntettének törvényi tényállásán belül, hanem speciális törvényi tényállásban, a kerítésben is büntetni rendeli. Ezen álláspont szerint a tizennyolcadik életévét be nem töltött passzív alany sérelmére elkövetett kerítés büntette - amely két évtől nyolc évig terjedő szabadságvesztéssel büntetendő -, és a jóval súlyosabban, öt évtől tizenöt évig terjedő szabadságvesztés büntetéssel büntetendő, a Btk. 192. § (2) bekezdés a) pontjára, és a (4) bekezdésre figyelemmel az (5) bekezdés a)

11 A Büntető Törvénykönyvről szóló 1978. évi IV. törvény közlönyállapot 2013. IV. 30.

12 A Büntető Törvénykönyvről szóló 2012. évi C. törvény 193. §-ának indokolása közlönyállapot 2021. VII. 8. - 2021. XII. 31. 
pontja szerinti, tizennyolcadik életévét be nem töltött személy sérelmére, szexuális cselekmény végzésére rábírással elkövetett emberkereskedelem büntettének kollíziója esetén - a specialitás elvére figyelemmel - az előbbi büncselekmény megállapítása indokolt, ellenkező esetben a Btk. 200. § (4) bekezdésének a) pontjában meghatározott minősített kerítés büntette a jogalkalmazói gyakorlatban nem lenne megállapítható, e tényállás kiüresedne.

Ezen álláspont az alábbiakra figyelemmel nem megalapozott.

A jogalkalmazást nem befolyásolhatja az a lehetőség, hogy valamely Btk.ban szabályozott tényállás - adott esetben jogalkotási hiba miatt - kiüresedik, a jogalkalmazói gyakorlatban nem kerül alkalmazásra.

A tizennyolcadik életévét be nem töltött személy fogalma nem is azonosítható a kiszolgáltatott helyzetben lévő személy fogalmával. A Legfőbb Ügyészség emberkereskedelem tárgyában kiadott iránymutatása sem tett egyenlőségjelet a két fogalom közé, hanem azt határozta meg, hogy a tizennyolcadik életévét be nem töltött passzív alany esetén különös gondot kell fordítani a kiszolgáltatott helyzet vizsgálatára, figyelemmel többek között a Palermói Egyezményben és az Európai Parlament és Tanácsi Irányelvben megfogalmazottakra.

A 2020. július 1. napjától hatályos Btk. is egyértelművé tette, hogy a passzív alany kiszolgáltatott helyzete nem azonos az elkövető által okozott megtévesztés hatásával, az elkövetőnek a passzív alannyal kapcsolatban fennálló hatalmi viszonyával, az elkövető által alkalmazott eröszak vagy fenyegetés hatásával, és a passzív alany tizennyolcadik életév alatti voltával. A törvény ugyanis taxatíve felsorolja az elkövetőnek a passzív alany felett hatalmat biztosító körülményeket, amelyek között a kiszolgáltatott helyzetet külön nevesíti, azt a többi körülménytől elkülöníti.

A Btk. 200. § (4) bekezdése a 200. § (1) bekezdésére visszautalva minősíti súlyosabban a kerítés büncselekményét, ha a passzív alany tizennyolcadik életévét be nem töltött személy, azaz a (4) bekezdés az alapesetre utal vissza, és így nem jelenik meg benne sem az üzletszerü kerítéshez szükséges rendszeres haszonszerzési cél, sem az emberkereskedelem és kényszermunka megállapításához szükséges rendszeres előnyszerzési cél.

A fentiekre figyelemmel a tizennyolcadik életévét be nem töltött, kiszolgáltatott helyzetben lévő, szexuális cselekmény elvégzésére rábírt vagy kényszerített személy rendszeres előnyszerzési céllal történő kihasználása (emberkereskedelem és kényszermunka) semmiképpen nem azonosítható a tizennyolcadik életévét be nem töltött személy haszonszerzés céljából másnak történő megszerzésével (kerítés alapesete).

A fentiek alapján a tizennyolcadik életévét be nem töltött, kiszolgáltatott helyzetben lévő, szexuális cselekmény elvégzésére rábírt vagy kényszerített személy 
rendszeres előnyszerzési céllal történő kihasználása (emberkereskedelem és kényszermunka) szintén nem azonosítható a 18. életévét be nem töltött személy megtévesztéssel, erőszakkal vagy fenyegetéssel történő, haszonszerzés céljából másnak megszerzésével (kerítés minősített esete).

Látható tehát egyrészt, hogy a két törvényi tényállás nem fedi le egymást, másrészt pedig, hogy a kerítés nem speciális az emberkereskedelem és kényszermunkához képest.

\section{Emberkereskedelem és kényszermunka, valamint a gyermekprostitúció kihasználásának viszonya}

2020. július 1. napjától a Btk. 192. § (8) bekezdés b) pontja szerinti „fogyasztói” típusú emberkereskedelem, és a Btk. 203. § (2) bekezdés szerinti gyermekprostitúció kihasználása kollíziójával is számolni kell, figyelemmel arra, hogy mindkét törvényi tényállás a kiskorú személy által végzett szexuális cselekmény igénybe vevőjét rendeli büntetni. Ugyanakkor a két diszpozíció között jelentős különbségek észlelhetők.

Amennyiben az elkövető kiskorú személy szexuális cselekményéért ellenszolgáltatást nyújt, gyermekprostitúció kihasználásáért két évtől nyolc évig terjedő szabadságvesztéssel büntetendő, ha a kiskorú személy nem emberkereskedelem áldozata, vagy az elkövető nem tud arról, hogy az lenne, illetve ilyen tudattartalma nem bizonyítható.

Ugyanakkor, ha az elkövető kiskorú személy szexuális cselekményét akár ingyenesen, akár ellenszolgáltatás fejében úgy veszi igénybe, hogy tud arról, hogy a passzív alany emberkereskedelem áldozata, emberkereskedelem miatt öt évig terjedő szabadságvesztéssel büntetendő.

Ebből következően, ha az elkövető a kiskorú személy szexuális cselekményéért ellenszolgáltatást nyújt úgy, hogy tisztában van azzal, hogy a kiskorú emberkereskedelem áldozata, a cselekmény akkor is a súlyosabb büntetési tétellel fenyegetett, a Btk. 203. §-ának (2) bekezdése szerinti gyermekprostitúció kihasználásaként minősül. Amennyiben a fogyasztói magatartást tanúsító személy a kiskorú szexuális cselekményéért ellenszolgáltatást nem nyújt, de tudja, hogy a passzív alany egyben emberkereskedelem áldozata, az enyhébben büntetendő Btk. 192. § (8) bekezdésébe ütköző „fogyasztói” típusú emberkereskedelem elkövetéséért tartozik büntetőjogi felelősséggel.

Ugyanakkor az elkövető aktuális tudattartalmának vizsgálata nélkül, anélkül, hogy bizonyításra kerülne az, hogy az úgynevezett fogyasztó tisztában volt azzal, hogy az általa igénybe vett, felhasznált személy emberkereskedelem áldozata, 
bünössége nem bizonyítható, erre vonatkozó közvetlen bizonyíték léte és beszerzése - a beismerésen kívül - ritka, a közvetett, tényből tényre következtetésre alapot adó bizonyítékok pedig ritkán alkotnak bünösség megállapításához elegendő zárt láncot.

\section{Az ,önkéntes szexmunka” és társai ellenértéke}

A gyakorlatban számos esetben merül fel problémaként az, hogy nem állapítható meg, hogy az emberkereskedelem és kényszermunka passzív alanya mekkora bevételre tett szert, mekkora bevételtől esett el, vagy más megközelítésben az elkövető milyen összegü vagyonnal gyarapodott, illetve, hogy több terhelt esetén vagyonuk milyen arányban gyarapodott az elkövetés révén. Azaz sok esetben a jogalkalmazás során nem lehet megállapítani a vagyonelkobzás alapját képező összeget, és ez pedig azt eredményezi, hogy a törvény kötelezö rendelkezése ellenére nem kerül sor ezen intézkedés alkalmazására.

Az elkövetői vagyongyarapodást legtöbbször azért nem lehet, vagy nem lehet pontosan rögzíteni, mert a passzív alanyok nem nyilatkoznak, vagy nem tudnak pontosan nyilatkozni arról, hogy az elkövetőknek mennyi pénzt adtak át az általuk végzett szexuális cselekményekből származó bevételükből, illetve munkacélú emberkereskedelem esetén (ideértve a házi szolgaságot is) jellemzően a passzív alanyok nem is jutnak semmilyen bevételhez. Ugyanakkor azonban bár összegekről a passzív alanyok nem tudnak nyilatkozni, de azt jellemzően meg tudják mondani, hogy legalább mennyi ideig végezték az adott tevékenységet.

Ezekben az esetekben megoldást jelenthetne például a meg nem lévő kábítószer hatóanyagtartalmának kvázi becsléssel (a szakértői intézet által adott időszakban adott kábítószerre rögzített legkisebb hatóanyagtartalom alapul vételével) történő megállapításának módszertanát alkalmazva, az adott időszakra vonatkozó minimálbér összegét elfogadva meghatározni a vagyonelkobzás alapját képező összeget.

Mind a szexuális cselekményt végző, mind a munkavégzésre, mind az egyéb szolgáltatásra igénybe vett passzív alanyok gyakorlatilag illegálisan foglalkoztatott munkavállalók. A munka ellenértéke a munkabér, a minimálbér pedig olyan napi, heti vagy havi munkabér, melyet a munkaadó köteles a munkavállaló számára megfizetni munkaviszonya alatt. A minimálbér összege 2000. január 1-je óta kormányrendeletben pontosan meghatározott óra, nap, hét, hónap lebontásban.

Több elkövető esetén a vagyonelkobzás arányának meghatározása nehezebb, hiszen e körben jellemzően a passzív alanyok rendelkeznek a legkevesebb 
információval. Vallomásaikban arra tudnak nyilatkozni - de erre meglehetős pontossággal -, hogy a bevételüket vagy annak egy részét mely elkövetőnek kellett odaadniuk, illetve, hogy tudomásuk szerint az kihez jutott el, kihez kellett eljuttatni azt a futároknak, közvetítőknek, ki volt adott esetben az irányító vagy a bünszervezet feje.

Figyelemmel kell azonban lenni arra, hogy amennyiben a passzív alanyok polgári jogi igényt terjesztenek elö, a vagyonelkobzás nem jöhet szóba. A nyomozások során ezért gondot kell fordítani arra, hogy a passzív alanyokat megfelelően tájékoztassa a nyomozó hatóság arról, hogy a sérelmükre elkövetett büncselekmény közvetlen következtében keletkezett kárukat polgári jogi igényként érvényesíthetik a terheltekkel szemben.

Mindemellett a Btk. 74/A. § (2) bekezdés c) és d) pontjai értelmében az ellenkező bizonyításáig vagyonelkobzás alá eső vagyonnak kell tekinteni, és vagyonelkobzást kell elrendelni arra a vagyonra is, amelyet az emberkereskedelem és kényszermunka, a kerítés, a prostitúció elősegítése, a kitartottság, a gyermekprostitúció kihasználása, a gyermekpornográfia elkövetője a büntetőeljárás megindítását megelőző öt évben szerzett, ha a vagyon, illetve az elkövető életvitele az igazolható jövedelmi viszonyaihoz, személyi körülményeihez képest különösen aránytalan.

Ezen büncselekmények miatt indult büntetőeljárásban nem azt kell megállapítani, hogy az adott vagyon milyen konkrét büncselekményből származik, elegendő, ha észszerüen feltételezhető, hogy az adott vagyont valamilyen büncselekmény - és nem más, jogszerü tevékenység - útján szerezték. ${ }^{13}$

\section{Befejezés}

A szabályozást koherensebbé és átláthatóbbá tevő jogalkotói szándék álláspontom szerint maradéktalanul nem valósult meg, és a gyakorlat pillanatnyilag számos, a tanulmányban nem is érintett problémával küzd. A jogalkalmazást nagyban segítik majd a jogerős, adott esetben a Kúria által is megvizsgált ítéletek, addig azonban buktatókkal tarkított, rögös út vár ránk.

13 A Büntető Törvénykönyvről szóló 2012. évi C. törvény 74/A. §-ának indokolása közlönyállapot 2021. VII.8.-2021. XII. 31. 


\section{Felhasznált irodalom}

Miskolczi B. (2021). Tiltott toborzás. In Polt P. (Szerk.), A Büntető Törvénykönyv kommentárja (pp. 35-48). HVG-ORAC Lap- és Könyvkiadó.

\section{A cikkben található online hivatkozások}

URL1: Kiszolgáltatott. https://szinonimaszotar.hu/keres/kiszolg\%C3\%A1ltatott

URL2: Kiszolgáltatott, sebezhetö ügyfelek a prémium- és privátbanki szegmensben. https://private-banking.hu/penz-befektetes/kiszolgaltatott-sebezheto-ugyfelek-a-premium-es-privatbanki-szegmensben-89

\section{Alkalmazott jogszabályok}

2012. évi C. törvény a Büntető Törvénykönyvről

2006. évi CII. tv. az Egyesült Nemzetek keretében, Palermóban, 2000. december 14-én létrejött, a nemzetközi szervezett bünözés elleni egyezménynek az emberkereskedelem, különösen a nők és gyermekek kereskedelme megelőzéséről, visszaszorításáról és büntetéséről szóló jegyzőkönyve kihirdetéséröl

2012. évi C. törvény a Büntető Törvénykönyvről

1978. évi IV. törvény a Büntető Törvénykönyvről

Kúria 2/2018. számú BJE határozata

Kúria 2/2018. számú BJE határozata

\section{A cikk APA szabály szerinti hivatkozása}

Huszár J. (2022). Emberkereskedelem újragondolva - a 2020. július 1-jén hatályba lépett rendelkezések hatékonysága ügyészi szemmel. Belügyi Szemle, 70(2), 305-325. https://doi. org/10.38146/BSZ.2022.2.5 